\title{
Bacterial Leaf Scorch of Landscape Trees: What We Know and What We Do Not Know
}

\author{
James L. Sherald
}

\begin{abstract}
Xylella fastidiosa has been recognized as a pathogen of landscape trees for over 25 years. Collectively, these diseases are referred to as bacterial leaf scorch (BLS). Arborists, property owners, and communities are now beginning to recognize BLS as a serious threat to the urban forest. Although advances in symptom awareness and diagnostic techniques have enabled arborists to diagnose BLS, there are many questions regarding host range, transmission, pathogeneses, disease management, and individual tree therapy that remain unanswered.
\end{abstract}

Key Words. Alternative hosts; BLS; leafhoppers; Pierce's disease; Xylella fastidiosa.

Diseases caused by the fastidious, xylem-limited bacterium Xylella fastidiosa have been known for well over 100 years. Pierce's disease of grape, or the California vine disease, was reported in California, U.S. in 1892 (Pierce 1892) and phony disease of peach, a dwarfing disorder, was reported in Georgia in the late 1880s (Cochran and Hutchins 1974). At first, the relatedness of these disorders was not recognized; however, both diseases were thought to be viral in nature and transmissible by grafting and by leafhoppers. The first indication of a bacterial etiology occurred in 1971 when the antibiotic tetracycline was shown to suppress the symptoms of Pierce's disease (Hopkins and Mortensen 1971). Later, electron microscopy showed the presence of rippled-walled, rickettsia-like bacteria in xylem tissue of symptomatic grape and peach (Goheen et al. 1973; Hopkins and Mollenhauer 1973; Hopkins et al. 1973; Nyland et al. 1973). Successful isolation of the pathogen by Davis et al. (1978) led to the description of $X$. fastidiosa as a new species of plant pathogenic bacteria in 1987 (Wells et al. 1987). Since then, X. fastidiosa has been associated with several major diseases (Table 1).

Diseases caused by $X$. fastidiosa are confined primarily to the Americas, where they have significant economic importance for several major crops such as grape, alfalfa, peach, almond, citrus, and coffee. The recent arrival of the glassywinged sharpshooter leafhopper in California in the 1990s has greatly increased the economic threat of Pierce's disease, almond leaf scorch, and oleander leaf scorch (Purcell and Saunders 1999a).

Xylella fastidiosa has been recognized as a pathogen of landscape trees since 1980 when xylem-limited bacteria serologically related to the Pierce's disease bacterium were found in leaf scorch-affected elms, sycamores, and oaks (Hearon et al. 1980). Over the last 25 years, X. fastidiosa has been found in over 40 species of landscape trees (Table 2). Leaf scorch diseases caused by X. fastidiosa are commonly referred to as bacterial leaf scorch (BLS). Today, BLS of elm, oak, and sycamore are recognized as major diseases of street and landscape trees in the mid-Atlantic and southeastern United States (Sherald 2001; Gould and Lashomb 2005).

BLS is a chronic disorder that affects trees over many years. Symptoms first appear in a single branch or segment of the crown and spread through the crown in subsequent years. Leaf symptoms develop in midsummer and progress in severity toward fall. Depending on the species, leaves develop various patterns of marginal and interveinal necrosis (Sherald 2001; Gould and Lashomb 2005). Elms develop a distinct undulating marginal necrosis bordered by a chlorotic halo; sycamores develop an irregular interveinal necrosis with zones of light and dark reddish brown tissue. In both elm and sycamore, symptoms usually progress in severity from the older to the younger leaves on the branch and affected leaves abscise early. Some oak species develop a marginal necrosis with a reddish band of tissue separating necrotic from green tissue. However, symptoms are not always distinct. In pin oak, BLS simply appears as early senescence with no distinct pattern of necrosis. Reductions in growth and seed set, as well as flower bud abortion, have all been reported in some hosts. Although BLS is a vascular disease, there is no vascular discoloration. Long-affected trees eventually develop dieback, which may be a consequence of BLS as well as other factors affecting the stressed tree. Infected trees are usually removed before they die because of their appearance or potential hazard.

Recognition of $X$. fastidiosa as a pathogen of landscape trees has been an important advance, because many leaf scorch and decline symptoms in trees were previously attrib- 
Table 1. Diseases caused by Xylella fastidiosa.

\begin{tabular}{ll}
\hline Disease & Reference \\
\hline $\begin{array}{l}\text { Alfalfa dwarf } \\
\text { Almond leaf scorch } \\
\text { Bacterial leaf scorch of } \\
\quad \text { landscape trees (BLS) }\end{array}$ & $\begin{array}{l}\text { Goheen et al. 1973 } \\
\text { Mircetich et al.1976 }\end{array}$ \\
$\begin{array}{l}\text { Citrus variegated chlorosis } \\
\text { Coffee leaf scorch }\end{array}$ & $\begin{array}{l}\text { Chang et al. 1993; Lee et al. 1993 } \\
\text { deLima 1998 }\end{array}$ \\
$\begin{array}{l}\text { Oleander leaf scorch } \\
\text { Peach phony disease }\end{array}$ & $\begin{array}{l}\text { Purcell et al. 1999c } \\
\text { Pecan leaf scorch }\end{array}$ \\
$\begin{array}{l}\text { Periwinkle wilt } \\
\text { Pierce's disease of grape }\end{array}$ & $\begin{array}{l}\text { Leu and Seu 1993 1973 } \\
\text { McCoy et al. 1978 }\end{array}$ \\
Plum leaf scald & and Moen et al. 1973; Hopkins \\
\hline
\end{tabular}

uted, and sometimes treated, for various other biotic and abiotic disorders. Although recognition of the pathogen is an important first step, there are many unanswered questions about $X$. fastidiosa and the diseases it causes in landscape tress.

The economic consequences of $X$. fastidiosa in agronomic commodities such as grape, almond, citrus, and coffee are well recognized and provide significant impetus and support for research that indirectly benefits our understanding of BLS. Although some local and statewide surveys of BLS have been performed (Sherald et al. 1994; Sherald 2001; Lashomb et al. 2002), the compensatory and ecological losses caused by $X$. fastidiosa in the urban forest are only barely appreciated. A survey of oaks in several New Jersey communities found $30 \%$ to $35 \%$ of the highly susceptible oak species exhibiting symptoms. The economic impact of the disease was estimated to be between $\$ 0.7$ and $\$ 1.6$ million over the next 10 years (Gould et al. 2004). Hopefully, further studies like this will heighten the awareness of the significance of these diseases and encourage support for the research needed to answer the questions presented in this article.

\section{HOST RANGE}

Xylella fastidiosa has a wide host range, including over 150 species in 30 families of dicotyledonous and monocotyledonous plants (Freitag 1951; Raju et al. 1980; Raju et al. 1983; Hopkins and Adlerz 1988; Hill and Purcell 1995; McElrone et al. 1999; Hartman et al. 2001; Costa et al. 2004; Wistrom and Purcell, 2005; Shapland et al. 2006; XYLELLA FASTIDIOSA 2006). Currently, more than 40 tree species have been identified as hosts (Table 2). Although X. fastidiosa is difficult to isolate and grow in culture, diagnostic tools such as enzyme-linked immunosorbent assay (Sherald and Lei 1991), polymerase chain reaction (PCR) (Pooler and Hartung 1995), and immunomagnetic separation followed by PCR (Pooler et al. 1997) can detect X. fastidiosa in tissue extracts.
Undoubtedly, additional hosts, including trees and other landscape plants, will continue to be discovered using these and possibly other tools. Although many hosts are asymptomatic, they may still provide an alternative source of inoculum for tree infections. The high incidence of Pierce's disease along the edges of vineyards has demonstrated that alternative hosts inhabiting the riparian edges are the primary source of inoculum (Hewitt et al. 1949; Goodwin and Purcell 1992). Hosts such as porcelain berry (Ampelopsis brevipedunculata), Asiatic bittersweet (Celastrus orbiculatus), mugwort (Artemisia spp.), goldenrod (Solidago fistulosa), English ivy (Hedera helix), Virginia creeper (Parthenocissus quinquefolia), periwinkle (Vinca major), blackberry (Rubus spp.), Bermuda grass (Cynodon dactylon), annual bluegrass (Роа аппиа), perennial ryegrass (Lolium perenne), elderberry (Sambucus spp.), and wild grape (Vitis spp.) (Freitag 1951; Hopkins and Adlerz 1988; Sherald and Kostka 1992; McElrone et al. 1999; Hartman et al. 2001; XYLELLA FASTIDIOSA 2006) are common cultivated or wild-edge inhabitants in suburban and urban landscapes. These hosts may be significant factors in BLS epidemiology and may account for the prevalence of BLS in landscape settings rather than in forests. However, although $X$. fastidiosa may multiply in many hosts, not all hosts will support large bacterial populations nor will all hosts experience systemic spread of the pathogen (Hill and Purcell 1995; Purcell and Saunders 1999b; XYLELLA FASTIDIOSA 2006). Furthermore, their importance as alternative hosts also depends on their attractiveness to leafhoppers or other insect vectors. Therefore, it is unlikely that all alternative hosts pose equal threats to tree populations. Unraveling the relationships among tree hosts, alternative host reservoirs, and insect vectors is a major challenge with significant bearing on BLS management.

\section{TRANSMISSION}

Xylem-feeding, sharpshooter leafhoppers in the subfamily Cicadellinae were known vectors of the causal agents responsible for Pierce's disease, alfalfa dwarf, and phony peach disease long before $X$. fastidiosa was identified as the pathogen (Hewitt et al. 1942; Houston et al. 1947; Turner 1949; Turner and Pollard 1959). Today, at least 24 species of leafhoppers are known vectors of Pierce's disease (Frazier 1965) and 19 leafhopper species are vectors of alfalfa dwarf (Frazier 1944; Frazier and Freitag 1946). Four species of spittlebug, family Cercopidae, were found to be capable of transmitting $X$. fastidiosa in Pierce's disease and alfalfa dwarf (Severin 1950). The glassy-winged sharpshooter (Homalodisca coagulata), GWSS, is one of the most important vectors. GWSS is endemic to the southeastern United States, where it is a major vector of $X$. fastidiosa in peach and grape. Since its arrival in California in the 1990s, it has become a serious threat to the California grape and almond industry and may become a threat to the citrus industry if the $X$. fastidiosa strains respon- 
Table 2. Tree Hosts of Xylella fastidiosa.

\begin{tabular}{|c|c|c|}
\hline Scientific name & Common name & Reference $^{\mathrm{z}}$ \\
\hline Albizia julibrissin & Silk tree & Wong et al. 2004 \\
\hline Acer negundo & Boxelder & McElrone et al. 1999 \\
\hline A. rubrum & Red maple & Sherald et al. 1987; Blake 1993; Hartman et al. 1996 \\
\hline A. saccharinum & Silver maple & Hartman 2002 \\
\hline A. saccharum & Sugar maple & Hartman et al. 1996 \\
\hline Cercis occidentalis & Western redbud & Wong et al. 2004 \\
\hline Celtis occidentalis & Hackberry & Beale et al. 2002 \\
\hline Fagus crenata & Japanese beech (bonsai) & Huang et al. 2003 \\
\hline Ginkgo biloba & Maidenhair tree & Wong et al. 2004 \\
\hline Jacaranda mimosifolia & Jacaranda & Wong et al. 2004 \\
\hline Juglans & Walnut & Wong et al. 2004 \\
\hline Liquidambar stryaciflua & Sweetgum & Long 1994; Hartman et al. 1996; Wong et al. 2004 \\
\hline P. $\times$ acerifolia & London Plane & Sherald 2001 \\
\hline P. mexicana & Mexican sycamore & Sherald 2001 \\
\hline Olea europea & Olive & Wong et al. 2004 \\
\hline Phoenix reclinata & Senegal date palm & Wong et al. 2004 \\
\hline Prunus cerasifera & Ornamental palm & Wong et al. 2004 \\
\hline Quercus alba & White oak & Long 1994 \\
\hline Q. bicolor & Swamp oak & Long 1994 \\
\hline Q. coccinea & Scarlet oak & Hearon et al. 1980; Kostka et al. 1984; Long 1994 \\
\hline Q. falcata & Southern red oak & Hopkins and Adlerz 1988 \\
\hline Q. imbricaria & Shingle oak & Hartman et al. 1995; $\mathrm{LG}^{\mathrm{z}}$ \\
\hline Q. incna & Bluejack oak & Barnard et al. 1998 \\
\hline Q. rubra & Northern red oak & Long 1994; Hartman et al. 1995; Hearon et al. 1980 \\
\hline Q. shumardii & Shumard oak & Mullen 1993; LG \\
\hline Q. stellata & Post oak & Long 1994 \\
\hline Q. velutina & Black oak & Huang 2003 \\
\hline Q. virginiana & Live oak & Mullen 1993 \\
\hline Ulmus americana & American elm & Wester and Jylkka 1959; Sherald 1993 \\
\hline U. glabra & Wych elm & Kostka et al. 1982 \\
\hline U. pumila & Siberian elm & Kostka et al. 1982 \\
\hline
\end{tabular}

${ }^{\mathrm{z}} \mathrm{LG}=$ Longwood Gardens, Kennett Square, PA (pers. comm.).

sible for citrus variegated chlorosis are introduced (Purcell and Saunders 1999a; XYLELLA FASTIDIOSA 2006).

Currently, no insects have been proven to be vectors of $X$. fastidiosa in landscape trees. However, $X$. fastidiosa has been found in seven leafhopper species captured on elm and oak and some of these are recognized vectors of $X$. fastidiosa in other diseases (Bentz and Sherald 2001). In addition to known sharpshooter leafhopper vectors, three species of treehopper, which are abundant in oak, were also been found carrying $X$. fastidiosa (Bentz and Sherald 2001). Treehoppers could be a new group of vectors that play a significant role in the transmission of $X$. fastidiosa in trees.

It should be recognized that although many leafhoppers may carry $X$. fastidiosa, they are not equally efficient in trans- 
mission. Successful transmission is driven by several factors, including their affinity for the host, seasonal host susceptibility, and the vector's feeding habits (Day and Bennetts 1954; Turner and Pollard 1955; Purcell 1979). Determining the vectors is essential in understanding the epidemiology of BLS. Once vectors have been identified, factors such as their preferred habitat, alternative host preferences, and seasonal periods of transmission can be examined. Knowing the vectors and understanding their biology is fundamental in devising disease management strategies.

Xylella fastidiosa is a graft-transmissible, systemic pathogen and caution should be exercised in the vegetative propagation of susceptible hosts. There is potential for root graft transmission; however, there is no epidemiological or direct evidence that root graft transmission of $X$. fastidiosa occurs in landscape trees. Root graft transmission should be investigated because the opportunities for root grafts are common in landscape settings. Natural root graft transmission of citrus variegated chlorosis has been demonstrated in potted sweet oranges (He et al. 2000).

Because $X$. fastidiosa has been notoriously difficult to isolate and grow in culture, it is assumed that there is little likelihood of it being mechanically transmitted in the course of routine pruning. However, until this avenue of transmission is experimentally proven to be ineffective, caution is still warranted and pruning tools should be disinfected.

\section{PATHOGEN}

Xylella fastidiosa is a Gram-negative, rod-shaped bacterium that has specific nutritional requirements. Based on an analysis of 25 strains isolated from ten hosts, $X$. fastidiosa was described as a single species (Wells et al. 1987). However, genetic and phenotypic variation within the species has long been recognized and host-specific pathotypes have been identified. For example, strains shown to cause Pierce's disease of grape also cause almond leaf scorch and alfalfa dwarf (Mircetich et al. 1976; Davis et al. 1980). Similarly, the strain or strains responsible for phony peach disease are also responsible for plum leaf scald (Wells et al. 1981). Strains causing citrus variegated chlorosis (CVC) are closely related to strains responsible for coffee leaf scorch (CLS) and can cause CLS symptoms when inoculated into coffee ( $\mathrm{Li}$ et al. 2001). Strain relationships become more complex when genetically distinct strains cause similar symptoms in the same host. Strains responsible for CVC and CLS are readily distinguishable from Pierce's disease strains yet can cause Pierce's disease symptoms in grape, whereas Pierce's disease strains do not cause symptoms in citrus ( $\mathrm{Li}$ et al. 2002). Reciprocal transmission studies involving shade trees have only been performed with isolates from elm and sycamore and in this study, symptoms could only be produced in the species from which the isolate was obtained (Sherald 1993).
Recently, three subspecies of $X$. fastidiosa have been described: two North American subspecies, $X$. fastidiosa subsp. pierce $i$ and X. fastidiosa subsp. multiplex, and a South American subspecies, X. fastidiosa subsp. pauca (Schaad et al. 2004). A fourth subspecies, $X$. fastidiosa subsp. sandyi, has also been proposed for oleander leaf scorch isolates (Schuenzel et al. 2005). Subspecies classification of $X$. fastidiosa strains responsible for BLS is far from resolved. Oak leaf scorch strains have been placed in X. fastidiosa subsp. multiplex (Schuenzel et al. 2005). Schaad et al. (2004) have placed a maple strain in $X$. fastidiosa subsp. piercei and sycamore and elm strains in X. fastidiosa subsp. multiplex. Although strains may be readily distinguished by molecular and genetic techniques, host response is the most meaningful test of strain significance and the hardest to demonstrate. The relationships of strains to hosts, both primary and alternative, as well as to insect vectors are numerous, complex, and very difficult to unravel. Understanding these relationships may have important disease management implications.

Survival and growth of $X$. fastidiosa are likely dependent on several factors, including temperature. Studies of Pierce's disease strains have shown that rapid growth occurs between 25 and $32^{\circ} \mathrm{C}\left(77^{\circ} \mathrm{F}\right.$ and $\left.89.6^{\circ} \mathrm{F}\right)$. Temperatures below $12^{\circ} \mathrm{C}$ to $17^{\circ} \mathrm{C}\left(53.6^{\circ} \mathrm{F}\right.$ to $\left.62.6^{\circ} \mathrm{F}\right)$ and above $34^{\circ} \mathrm{C}\left(93.2^{\circ} \mathrm{F}\right)$ adversely affect survival of the pathogen (Feil and Purcell 2001). The significance of warm temperatures is demonstrated by the fact that symptoms of Pierce's disease appear earlier in warmer areas and expand beyond their normal range after mild winters (Feil and Purcell 2001). Temperature optimums have not been determined for strains associated with landscape trees. Occurrences of BLS in Kentucky, Pennsylvania, New Jersey, New York, and southern Ontario suggest a greater tolerance of colder temperatures. However, like Pierce's disease and the other diseases caused by X. fastidi$o s a$, BLS occurs predominantly in the southern and midAtlantic states where winters are mild. As global warming increases, BLS may expand further north and the incidence and severity of these diseases could increase throughout their range. This would be a consequence of several factors, including an increase in the survival and growth of the pathogen, an increase in the growing season and period of susceptibility of the host, and an increase in heat and moisture stress.

\section{PATHOGENESIS}

The process by which $X$. fastidiosa causes disease is not completely understood. Phytotoxins, growth regulator imbalance, and water stress have all been considered possible mechanisms of pathogenesis (Hopkins 1989). Physiological studies have shown a relationship between occluded vessels and symptom development in grape (Hopkins et al. 1977, 1981). In elm, Kostka et al. (1986a) showed a reduction in stem hydraulic conductivity and stem water potential in infected elms. Numerous observations of $X$. fastidiosa in planta 
have shown that bacteria occur in a slime-like matrix, or biofilm glycocalyx, which likely occludes tracheary elements (Mollenhauer and Hopkins 1974; Hearon et al. 1980; Chagas et al. 1992). Xylella fastidiosa is the first plant pathogen for which the complete genome has been sequenced, providing insight into the organism's pathogenic potential (Simpson et al. 2000). Examination of the genome found that $X$. fastidiosa has the capacity to produce biofilm extracellular polysaccharides (EPSs). Biofilms are significant in the pathogenesis of many plant and mammalian pathogens enabling bacteria to attach to the host, colonize, and share enzymatic functions. Mutants lacking the ability to produce EPSs are usually nonpathogenic. Marques et al. (2002) have proposed that the biofilm is a likely virulence factor in $X$. fastidiosa.

Intraplant movement is critical for pathogenicity. The genome showed evidence of pectolytic enzymes capable of breaching the pit membranes between vessels. Genes were also found for encoding proteins necessary for the development of fimbriae or pili that are commonly observed on the polar ends of $X$. fastidiosa. Pili play an important role in bacterial colonization, enabling bacteria to attach to each other as well as to insect and plant hosts. Pili also provide twitching motility, which enables $X$. fastidiosa to move upstream from the point of inoculation against acropetal sap flow (Meng et al. 2005).

The mechanisms of pathogenesis may vary among hosts. The presence of genes encoding for the metabolism of iron and other metals suggests that some symptoms such as leaf variegation in CVC may be a consequence of the reduction of essential micronutrients in xylem fluid (Simpson et al. 2000). It is interesting that in phony peach disease, alfalfa dwarf, and ragweed stunt, $X$. fastidiosa simply causes a reduction in growth. It remains to be seen whether this response is solely a consequence of a reduction in water transport or some other mechanism.

\section{MANAGEMENT}

Currently, we do not know how to limit the spread of BLS or how to cure a BLS-infected tree. Typically, the first line of defense in plant disease management is sanitation, the removal of infected hosts. However, the chronic nature of BLS means that infected trees can remain aesthetically acceptable in the landscape for a long time before they must be removed. Because we do not even know if direct spread from tree to tree is a common occurrence, it is probably not advisable to engage in an aggressive sanitation program to remove infected trees when their removal may have little value in limiting disease spread. In Pierce's disease, removal of infected grapes did not reduce spread (Hewitt et al. 1949).

The host range for $X$. fastidiosa is extensive and far from completely known. Identification and removal of alternative host reservoirs may be an effective approach in reducing the incidence of BLS. However, the significance of alternative reservoirs must first be confirmed. Some alternative hosts such as the invasive exotic species porcelain berry and Asiatic bittersweet are extremely pervasive and some leafhoppers can fly for long distances. Consequently, aggressive removal of these hosts over large areas will be difficult.

An important research priority is to determine the significant insect BLS vectors. Understanding their life histories, including range of flight, preferred habitats, and hosts, is essential to prescribe management strategies. Because leafhoppers are generally active for long periods and X. fastidiosa persists in the adults, long-term canopy protection with insecticides would be necessary. In the landscape, particularly in large municipal plantings, routine insecticide treatments are not an attractive or practical management approach. Management of vector habitats and alternative hosts may be useful. Pierce's disease occurs most commonly near riparian and other edge areas where leafhoppers overwinter and where alternative hosts occur (Hewitt et al. 1949; Purcell 1975; Goodwin and Purcell 1992). Recently, riparian vegetation management practices for Pierce's disease have been developed (Pierce's Disease/Riparian Habitat Workgroup 2000). These practices prescribe the removal of host plants preferred by the blue-green sharpshooter for reproduction as well as the removal of systemic alternative hosts of $X$. fastidiosa, particularly invasive exotics. These species are replaced with native riparian plants that are not preferred by leafhopper or $X$. fastidiosa hosts.

When symptoms first appear, if they are localized on a single branch, an attempt should be made to prune out the infection. The disease is chronic and in some hosts and individual trees, it may spread slowly, providing the opportunity to remove the infection before it becomes systemic throughout the tree. Because there is no way to know how far beyond the obvious symptoms the bacteria have gone, it is advisable to prune the branch as far beyond the visible symptoms as possible without destroying the aesthetic value of the tree. Studies to determine the spread of $X$. fastidiosa beyond obvious symptoms and the development of rapid techniques for tracing infections would be very helpful in directing therapeutic pruning. Pruning is being used to manage CVC in Brazil.

It has long been suspected that abiotic drought stress would exacerbate the effect of $X$. fastidiosa. McElrone et al. (2001) demonstrated that drought stress enhanced symptom progression and severity in Virginia creeper (Parthenocissus quinquefolia) artificially inoculated with $X$. fastidiosa. Horticultural practices that enhance root growth and minimize moisture stress may reduce symptom severity and prolong the life of infected trees.

Chemotherapy with injected oxytetracycline has caused symptom remission but has not been effective in curing infected trees (Kostka et al. 1985; Chang and Walker 1988). The growth regulator paclobutrazole (PBZ) has been found to 
reduce leaf scorch symptoms in oak (The Bartlett Tree Research Laboratories, pers. comm.). PBZ's growth regulator capacity may enhance the water efficiency of the plant, thus reducing symptom expression and the effect on the tree. Recent studies have also shown that PBZ at a rate of $20 \mu \mathrm{g} /$ $\mathrm{mL}^{-1}$, ten times higher than the labeled rate, reduced in vitro growth of X. fastidiosa (DeStephano 2005). The effect on in vitro growth may be a consequence of the disruption of sterol biosynthesis (Sugavanam 1984; Burden et al. 1987; Radenmacher 1987). These studies have been largely exploratory so there is still considerable research that should be done involving a range of host and pathogen-affecting compounds and methods of application, including integrated and repeated treatments. The chronic nature of BLS provides an expanded window for a series of therapies that may ultimately be necessary to cure infected trees. Novel approaches such as biological control may also hold promise. Recently, a benign strain of $X$. fastidiosa was found to be effective in providing induced resistance to Pierce's disease (Hopkins 2005).

The most lasting and practical approach to BLS management in landscape trees would be to find disease-tolerant selections. Tolerance has been found in grape, plum, and alfalfa and tolerance may exist in other hosts as well (Purcell 1979). Unfortunately, screening for tolerance is difficult because of the fastidious nature of the pathogen, the slow and erratic nature of symptom development, and the difficulties associated with working with woody plants. Genetic engineering is being considered in the development of Pierce's disease resistance and may also offer promise for landscape trees.

The recognition of $X$. fastidios $a$ as a pathogen of landscape trees has been a significant advance over the last 25 years. Previously, leaf scorch and decline symptoms have been incorrectly attributed to a wide range of abiotic stressors and pathogens. Now that we are able to diagnose BLS with confidence, we must focus research on the difficult questions presented here, which are pertinent to controlling the spread and treatment of BLS.

\section{LITERATURE CITED}

Barnard, E.L., E.C. Ash, D.L. Hopkins, and R.J. McGovern. 1998. Distribution of Xylella fastidiosa in oaks in Florida and its association with growth decline in Quercus laevis. Plant Disease 82:569-572.

Beale, J., P. Bachi, and J. Hartman. 2002. Landscape plant disease observations from the plant disease diagnostic laboratory-2002, pp. 22-23. In University of Kentucky Agricultural Experiment Station 2002 Nursery and Landscape Program Research Report. www.ca.uky.edu/agc/ pubs/pr/pr468/pr468.pdf (accessed 8/1/2006).

Bentz, J., and J.L. Sherald. 2001. Transmission of the xylemlimited bacterium Xylella fastidiosa to shade trees by insect vectors, pp. 203-208. In Ash, C. (Ed.). Shade Tree
Wilt Diseases. American Phytopathological Society, St. Paul, MN.

Blake, J.H. 1993. Distribution of Xylella fastidiosa in oak, maple, and sycamore in South Carolina. Plant Disease $77: 1262$.

Burden, R.S., G.A. Carter, T. Clark, D.T. Cooke, S.J. Croker, A.H.B. Deas, P. Hedden, C.S. James, and J.R. Lenton. 1987. Comparative activity of the enantiomers of triadimenol and paclobutrazol as inhibitors of fungal growth and plant sterol and gibberellin biosynthesis. Pesticide Science 21:253-267.

Chagas, C.M., V. Rossetti, and M.J.G. Beretta. 1992. Electron microscopy studies of a xylem-limited bacterium in sweet orange affected with citrus variegated chlorosis disease in Brazil. Journal of Phytopathology 134:306-312.

Chang, C.J., M. Garnier, L. Zreik, V. Rossetti, and J.M. Bove. 1993. Culture and serological detection of xylemlimited bacterium causing citrus variegated chlorosis and its identification as a strain of Xylella fastidiosa. Current Microbiology 27:137-142.

Chang, C.J., and J.T. Walker. 1988. Bacterial leaf scorch of northern red oak: Isolation, cultivation, and pathogenicity of a xylem-limited bacterium. Plant Disease 72:730-733.

Cochran, L.C., and L.M. Hutchins. 1974. Phony, pp. 96-103. In Virus Diseases and Noninfectious Disorders of Stone Fruits in North America. USDA Agricultural Handbook 437.

Costa, H.S., E. Raetz, T.R. Pinckard, C. Gispert, R. Hernandez-Martinez, C.K. Dumenyo, and D.A. Cooksey. 2004. Plant hosts of Xylella fastidiosa in and near southern California vineyards. Plant Disease 88:1255-1261.

Davis, M.J., A.H. Purcell, and S.V. Thomson. 1978. Pierce's disease of grapevines: Isolation of the causal bacterium. Science 199:75-77.

Davis, M.J., R.F. Whitcomb, and A.G. Gillaspie Jr. 1980. Fastidious bacteria of plant vascular tissue and invertebrates (including so-called rickettsia-like bacteria), pp. 2172-2188. In Starr, M.P., H.O. Stolp, H.G. Truper, A. Balows, and H.G. Schlegel (Eds.). The Prokaryotes: A Handbook on Habitats, Isolation, and Identification of Bacteria. Springer-Verlag, New York/Heidelberg/Berlin.

Day, M.F., and M.J. Bennetts. 1954. A Review of Problems of Specificity in Arthropod Vectors of Plant and Animal Viruses. C.S.I.R.O., Canberra, Australia.

deLima, J.E.O., V.S. Miranda, J.S. Hartung, R.H. Brlansky, A. Coutinho, S.R. Roberto, and E.F. Carlos. 1998. Coffee leaf scorch bacterium: Axenic culture, pathogenicity, and comparison with Xylella fastidiosa of citrus. Plant Disease 82:94-97.

DeStephano, D. 2005. Chemotherapeutic treatment options of Xylella fastidiosa in shade trees. M.S. Thesis, University of Maryland. https://drum.umd.edu/dspace/bitstream/ 1903/3251/1/umi-umd-3079.pdf (accessed 8/1/2006). 
Feil, H., and A.H. Purcell. 2001. Temperature-dependent growth and survival of Xylella fastidiosa in vitro and in potted grapevines. Plant Disease 85:1230-1234.

Frazier, N.W. 1944. Phylogenetic relationship of the nine known leafhopper vectors of Pierce's disease of grape. Phytopathology 34:1000.

- 1965. Xylem viruses and their insect vectors, pp. 91-99. In Proceedings International Conference on Virus and Virus Vectors on Perennial Hosts, with Special Reference to Vitis. University of California, Division of Agricultural Sciences, Davis, CA.

Frazier, N.W., and J.H. Freitag. 1946. Ten additional leafhopper vectors of the virus causing Pierce's disease of grapes. Phytopathology 36:634-637.

Freitag, J.H. 1951. Host range of the Pierce's disease virus of grapes as determined by insect transmission. Phytopathology 41:920-934.

Goheen, A.C., G. Nyland, and S.K. Lowe. 1973. Association of a rickettsialike organism with Pierce's disease of grapevines and alfalfa dwarf and heat therapy of the disease in grapevines. Phytopathology 63:341-345.

Goodwin, P.H., and A.H. Purcell. 1992. Pierce's disease, pp. 76-84. In Grape Pest Management, 2nd ed. University of California, Division of Agriculture and Natural Resources, Oakland, CA.

Gould, A.B., G. Hamilton, M. Vodak, J. Grabosky, and J. Lashomb. 2004. Bacterial leaf scorch of oak in New Jersey: Incidence and economic impact. Phytopathology 94:S36.

Gould, A.B., and J.H. Lashomb. 2005. Bacterial leaf scorch of shade trees. APSnet. www.apsnet.org/online/feature/ bls/ (accessed 8/1/2006).

Hartman, J. 2002. More landscape trees affected by bacterial leaf scorch. 2002. UK Cooperative Extension Service, Kentucky Pest News. 966:4. www.uky.edu/Agriculture/ kpn/kpnhome.htm (accessed 8/1/2006).

Hartman, J.R., B.C. Eshenaur, and U.E. Jarlfors. 1995. Bacterial leaf scorch caused by Xylella fastidiosa: A Kentucky survey; a unique pathogen; and bur oak, a new host. Journal of Arboriculture 21:77-82.

Hartman, J.R., U.E. Jarlfors, and W.M. Fountain 1996. First report of bacterial leaf scorch caused by Xylella fastidiosa on sugar maple and sweetgum. Plant Disease 80:1302.

Hartman, J.R., D. Saffray, and J. Beale. 2001. Presence of Xylella fastidiosa in symptomless landscape hosts, pp. 24-25. In 2001 Nursery and Landscape Program Research Report, UK Nursery and Landscape Program. www. ca.uky.edu/agc/pubs/pr/pr450/PR450.PDF (accessed 8/1/ 2006).

Haygood, R.A., W. Witcher, and R.K. Jones. 1988. Outbreak of sycamore leaf scorch in the Carolinas. Plant Disease $72: 644$.
He, C.X., W.B. Li, A.J. Ayres, J.S. Hartung, V.S. Miranda, and D.C. Teixeira. 2000. Distribution of Xylella fastidiosa in citrus rootstocks and transmission of citrus variegated chlorosis between sweet orange plants through natural root-grafts. Plant Disease 84:622-626.

Hearon, S.S., J.L. Sherald, and S.J. Kostka. 1980. Association of xylem-limited bacteria with elm, sycamore, and oak leaf scorch. Canadian Journal of Botany 58:1986-1993.

Hewitt, W.B., N.W. Frazier, and J.H. Freitag. 1949. Pierce's disease investigations. Hilgardia 19:207-264.

Hewitt, W.B., N.W. Frazier, and B.R. Houston. 1942. Transmission of Pierce's disease of grapevine with a leafhopper. Phytopathology 32:8.

Hill, B.L., and A.H. Purcell. 1995. Multiplication and movement of Xylella fastidiosa within grapevine and four other plants. Phytopathology 85:1368-1372.

Hopkins, D. 2005. Biological control of Pierce's disease in the vineyard with a benign strain of Xylella fastidiosa. Phytopathology 95:S44.

Hopkins, D.L. 1977. Diseases caused by leafhopper borne, rickettsia-like bacteria. Annual Review of Phytopathology 17:277-294.

1981. Seasonal concentration of the Pierce's disease bacterium in grapevine stems, petioles, and leaf veins. Phytopathology 71:415-418.

- 1989. Xylella fastidiosa: Xylem-limited bacterial pathogen of plants. Annual Review of Phytopathology 27:271-290.

Hopkins, D.L., and W.C. Adlerz. 1988. Natural hosts of $X y$ lella fastidiosa in Florida. Plant Disease 72:429-431.

Hopkins, D.L., and H.H. Mollenhauer. 1973. Rickettsia-like bacterium associated with Pierce's disease of grapes. Science 179:298-300.

Hopkins, D.L., H.H. Mollenhauer, and W.J. French. 1973. Occurrence of a rickettsia-like bacterium in the xylem of peach trees with phony disease. Phytopathology 63: 1422-1423.

Hopkins, D.L., and J.A. Mortensen. 1971. Suppression of Pierce's disease symptoms by tetracycline antibiotics. Plant Disease. Reporter 55:610-612.

Houston, B.R., K. Esau, and W.B. Hewitt. 1947. The mode of vector feeding and the tissues involved in the transmission of Pierce's disease virus in grape and alfalfa. Phytopathology 37:247-253.

Huang, Q. 2003. First report of Xylella fastidiosa associated with leaf scorch in black oak in Washington, DC. Plant Disease 88:224.

Huang, Q., W.N. Li, and J.S. Hartung. 2003. First report of Xylella fastidiosa in Japanese beech bonsai. Canadian Journal of Plant Pathology 25:401-405. 
Kitajima, E.W., M. Bakarcic, and M.V. Fernandez-Valiela. 1975. Association of rickettsia-like bacteria with plum leaf scald disease. Phytopathology 65:476-479.

Kostka, S.J., J.L. Sherald, and T.A. Tattar. 1982. Isolation of bacteria from three elm species and mulberry exhibiting leaf scorch. Phytopathology 72:936.

— 1984. Culture of fastidious, xylem-limited bacteria from declining oaks in the northeastern states. Phytopathology 74:803.

Kostka, S.J., T.A. Tattar, and J.L. Sherald. 1985. Suppression of bacterial leaf scorch symptoms in American elm through oxytetracycline microinjection. Journal of Arboriculture 11:54-58.

- 1986a. Elm leaf scorch: Abnormal physiology in American elms infected with fastidious, xylem-inhabiting bacteria. Canadian Journal of Forest Research 16: 1088-1091.

Kostka, S.J., T.A. Tattar, J.L. Sherald, and S.S. Hurtt. 1986 b. Mulberry leaf scorch, new disease caused by a fastidious, xylem-inhabiting bacterium. Plant Disease 70:690-693.

Lashomb, J., A. Iskra, A.B. Gould, and G. Hamilton (Eds.). 2002. Bacterial Leaf Scorch in Amenity Trees: A WideSpread Problem of Economic Significance to the Urban Forest. USDA Forest Service NA-TP-01-03.

Lee, R.F., M.J.G. Beretta, J.H. Hartung, M.E. Hooker, and K.S. Derrick. 1993. Citrus variegated chlorosis: Confirmation of a Xylella fastidiosa as the causal agent. Summa Phytopathologica 19:123-125.

Leu, L.S., and C.C. Seu. 1993. Isolation, cultivation, and pathogenicity of Xylella fastidiosa, the causal bacterium of pear leaf scorch disease. Plant Disease 77:642-646.

Li, W.-B., W.D. Pria Jr., D.C. Teixeira, V.S. Miranda, A.J. Ayres, C.F. Franco, M.G. Costa, C.-X. He, P.I. Costa, and J.S. Hartung. 2001. Coffee leaf scorch caused by a strain of Xylella fastidiosa from citrus. Plant Disease 85: 501-505.

Li, W.-B., C.-H. Zhou, W.D. Pria Jr., D.C. Teixeira, V.S. Miranda, E.O. Pereira, A.J. Ayres, C.-X. He, P.I. Costa, and J.S. Hartung. 2002. Citrus and coffee strains of Xylella fastidiosa induce Pierce's disease in grapevine. Plant Disease 86:1206-1210.

Long, E.A. 1994. Plant and Pest Diagnostic Center Sample. Summary for Bacterial Leaf Scorch (Xylella fastidiosa) 1988-1993. E\&PP Info Note 132 of the University of Tennessee Agricultural Extension Service. 3 pp.

Marques, L.L.R., H. Ceri, G.P. Manfio, D.M. Reid, and M.E. Olson. 2002. Characterization of biofilm formation by Xylella fastidiosa in vitro. Plant Disease 86:633-638.

McCoy, R.E., D.L. Thomas, J.H. Tsai, and W.J. French. 1978. Periwinkle wilt, a new disease associated with $\mathrm{xy}-$ lem delimited rickettsialike bacteria transmitted by a sharpshooter. Plant Disease Reporter 62:1022-1026.
McElrone, A.J., J.L. Sherald, and I.N. Forseth. 2001. Effects of water stress on symptomatology and growth of Parthenocissus quinquefolia infected by Xylella fastidiosa. Plant Disease 85:1160-1164.

McElrone, A.J., J.L. Sherald, and M.R. Pooler. 1999. Identification of alternative hosts of Xylella fastidiosa in the Washington, DC area using nested polymerase chain reaction (PCR). Journal of Arboriculture 25:258-263.

Meng, Y., Y. Li, C.D. Galvani, G. Hao, J.N. Turner, T.J. Burr, and H.C. Hoch. 2005. Upstream migration of $X y$ lella fastidiosa via pilus-driven twitching motility. Journal of Bacteriology 187:5560-5567.

Mircetich, S.M., S.K. Lowe, W.J. Moller, and G. Nyland. 1976. Etiology of almond leaf scorch disease and transmission of the causal agent. Phytopathology 66:17-24.

Mollenhauer, H.M., and D.L. Hopkins. 1974. Ultrastructural study of Pierce's disease bacterium in grape xylem tissue. Journal of Bacteriology 119:612-618.

Mullen, J. 1993. Regional Reports-Southeast Region, pp. 6-9. In Plant Diagnostician's Quarterly. Simone, G.W. (Ed.) XIV (3).

Nyland, G., A.C. Goheen, S.K. Lowe, and H.C. Kirkpatrick. 1973. The ultrastructure of a rickettsialike organism from a peach tree affected with phony disease. Phytopathology 63:1275-1278.

Pierce, N.B. 1892. The California vine disease. USDA, Division of Vegetable Pathology Bulletin 2:1-222.

Pierce's Disease/Riparian Habitat Workgroup. 2000. Information Manual: Riparian Vegetation Management for Pierce's Disease in North Coast California Vineyards. Insley, E., K. Gaffney, and E. Weber. www.cnr.berkeley. edu/xylella/north/info.htm (accessed 8/1/2006).

Pooler, M.R., and J.S. Hartung. 1995. Specific PCR detection and identification of Xylella fastidiosa strains causing citrus variegated chlorosis. Current Microbiology 31: 377-381.

Pooler, M.R., I.S. Myung, J. Bentz, J. Sherald, and J.S. Hartung. 1997. Detection of Xylella fastidiosa in potential insect vectors by immunomagnetic separation and nested polymerase chain reaction. Letters in Applied Microbiology 25:123-126.

Purcell, A.H. 1975. Role of the blue-green sharpshooter, Hordnia circellata, in the epidemiology of Pierce's disease of grapevines. Environmental Entomology 4: $745-752$.

- 1979. Leafhopper vectors of xylem-borne plant pathogens, pp. 603-625. In Harris, K.F., and K. Maramorosch (Eds.). Leafhopper Vectors and Plant Disease Agents. Academic Press, New York.

Purcell, A.H., and S.R. Saunders. 1999a. Glassy-winged sharpshooters expected to increase plant disease. California Agriculture 53:26-27. 
. 1999b. Fate of Pierce's disease strains of Xylella fastidiosa in common riparian plants in California. Plant Disease 83:825-830.

Purcell, A.H., S.R. Saunders, M. Hendson, M.E. Grebus, and M.J. Henry. 1999c. Causal role of Xylella fastidiosa in oleander leaf scorch disease. Phytopathology 89:53-58.

Radenmacher, W., H.M. Fritschm, J.E. Graebe, H. Sauter, and J. Jung. 1987. Tetcyclacis and triazole-type plant growth retardants: Their influence on the biosynthesis of gibberellins and other metabolic processes. Pesticide Science 21:241-252.

Raju, B.C., A.C. Goheen, and N.W. Frazier. 1983. Occurrence of Pierce's disease bacteria in plants and vectors in California. Phytopathology 73:1309-1313.

Raju, B.C., S.F. Nome, D.M. Docampo, A.C. Goheen, G. Nyland, and S.K. Lowe. 1980. Alternative hosts of Pierce's disease of grapevines that occur adjacent to grape growing areas in California. American Journal of Enology and Viticulture 31:144-148.

Randall, J.J., M. Radionenko, J.M. French, M.W. Olsen, N.P. Goldberg, and S.F. Hanson. 2007. Xylella fastidiosa detected in New Mexico in Chitalpa, a common landscape ornamental plant. Plant Disease 91:329.

Sanderlin, R.S., and K.I. Heyderich-Alger. 2000. Evidence that Xylella fastidiosa can cause leaf scorch disease of pecan. Plant Disease 84:1282-1286.

Schaad, N.W., E. Postnikova, G. Lacy, M.B. Fatmi, and C.-J. Chang. 2004. Xylella fastidiosa subspecies: X. fastidiosa subsp. piercei subsp. nov., X. fastidiosa subsp. multiplex subsp. nov., and X. fastidiosa subsp. pauca subsp. nov. Systematic and Applied Microbiology 27:290-300.

Schuenzel, E.L., M. Scally, R. Stouthamer, and L. Nunney. 2005. A multigene phylogenetic study of clonal diversity and divergence in North American strains of the plant pathogen Xylella fastidiosa. Applied and Environmental Microbiology 71:3832-3839.

Severin, H.H.P. 1950. Spittle-insect vectors of Pierce's disease virus. II. Life history and virus transmission. Hilgardia 19:357-382.

Shapland, E.B., K.M. Daane, G.Y. Yokota, C. Wistrom, J.H. Connell, R.A. Duncan, and M.A. Viveros. 2006. Ground vegetation survey for Xylella fastidiosa in California almond orchards. Plant Disease 90:905-909.

Sherald, J.L. 1993. Pathogenicity of Xylella fastidiosa in American elm and failure of reciprocal transmission between strains from elm and sycamore. Plant Disease 77: 190-193.

- 2001. Xylella fastidiosa, a bacterial pathogen of landscape trees, pp. 191-202. In Ash, C.L. (Ed.). Shade Tree Wilt Diseases. American Phytopathological Society, St. Paul, MN.

Sherald, J.L., S.S. Hearon, S.J. Kostka, and D.L. Morgan. 1983. Sycamore leaf scorch: Culture and pathogenicity of fastidious xylem-limited bacteria from scorch-affected trees. Plant Disease 67:849-852.

Sherald, J.L., and S.J. Kostka. 1992. Bacterial leaf scorch of landscape trees caused by Xylella fastidiosa. Journal of Arboriculture 18:57-63.

Sherald, J.L., and J.D. Lei. 1991. Evaluation of a rapid ELISA test kit for detection of Xylella fastidiosa in landscape trees. Plant Disease 75:200-203.

Sherald, J.L., E.N. Patton, T.M. Stidham, and C.L. Favre. 1994. Incidence and development of bacterial leaf scorch of elm on the National Mall. Journal of Arboriculture 20:18-23.

Sherald, J.L., J.M. Wells, S.S. Hurtt, and S.J. Kostka. 1987. Association of fastidious, xylem-inhabiting bacteria with leaf scorch in red maple. Plant Disease 71:930-933.

Simpson, A.J.G., F.C. Reinach, P. Arruda, et al. 2000. The genome sequence of the plant pathogen Xylella fastidiosa. Nature 406:151-157.

Sugavanam, B. 1984. Diastereoisomers and enantiomers of paclobutrazol: Their preparation and biological activity. Pesticide Science 15:296-302.

Turner, W.F. 1949. Insect vectors of phony peach disease. Science 109:87-88.

Turner, W.F., and H.N. Pollard. 1955. Additional leafhopper vectors of phony peach. Journal of Economic Entomology 48:771-772.

. 1959. Life Histories and Behavior of Five Insect Vectors of Phony Peach Disease. USDA Technical Bulletin 1188. $28 \mathrm{pp}$.

Wells, J.M., B.C. Raju, H.Y. Hung, W.G. Weisburg, L. Mandelco-Paul, and D.J. Brenner. 1987. Xylella fastidiosa gen. nov., sp. nov.: Gram-negative, xylem-limited, fastidious plant bacteria related to Xanthomonas spp. International Journal of Systematic Bacteriology 37:136-143.

Wells, J.M., B.C. Raju, J.M. Thomson, and S.K. Lowe. 1981. Evidence of the common etiology of phony peach and plum leaf scald diseases. Phytopathology 71:1156-1161.

Wester, H.V., and E.W. Jylkka. 1959. Elm scorch, graft transmissible virus of American elm. Plant Disease Reporter 43:519.

Wistrom, C., and A.H. Purcell. 2005. The fate of Xylella fastidiosa in vineyard weeds and other alternate hosts in California. Plant Disease 89:994-999.

Wong, F., D.A. Cooksey, and H.S. Costa. 2004. Documentation and characterization of Xylella fastidiosa strains in landscape hosts, pp. 238-241. In California Department of Food and Agriculture Symposium Proceedings, Pierce's Disease Research. Coronado, CA.

XYLELLA FASTIDIOSA-A scientific and community Internet resource on plant diseases caused by the bacterium 
Xylella fastidiosa. A.H. Purcell. www.cnr.berkeley.edu/ xylella/ (accessed 8/1/2006).

\section{James L. Sherald}

Chief, Natural Resources and Science

Center for Urban Ecology

National Capital Region

National Park Service

4598 MacArthur Boulevard, N.W.

Washington, DC 20007-4227, U.S.

jim_sherald@nps.gov

Résumé. Xylella fastidiosa a été reconnu comme étant un pathogène des arbres ornementaux depuis plus de 25 ans. Collectivement, ces maladies sont référencées sous le terme de roussissure bactérienne. Les arboriculteurs, les propriétaires et les municipalités commencent maintenant à reconnaître la roussissure bactérienne comme une menace sérieuse à la forêt urbaine. Alors que les avancées dans la surveillance des symptômes les techniques de diagnostic ont donné des moyens aux arboriculteurs pour diagnostiquer la roussissure bactérienne, il subsiste de nombreuses questions toujours non résolues en regard du champ de l'hôte, de la transmission, de la pathogénèse, de la gestion de la maladie et de la thérapie pour les arbres.

Zusammenfassung. Xylella fastidiosa ist seit über 25 Jahren als Pathogen bei Landschaftsgehölzen bekannt. Zusammenfassend spricht man bei diesem Erregerbild von Bakterieller Blattwelke oder BLS. Arboristen, Landeigentümer und Kommunen beginnen nun, diese Krankheit als eine ernsthafte Bedrohung für urbanes Grün zu sehen. Während Fortschritte in der Symptomerkennung und Diagnose-Techniken den Arboristen helfen, BLS zu diagnostizieren, so bleiben doch viele Fragen bezüglich des Wirtsspektrums, Übertragung, Pathogenese, Krankheits-Management und individuelle Baumtherapie offen

Resumen. Xylella fastidiosa ha sido reconocido por 25 años como un patógeno de los árboles urbanos. Colectivamente esta enfermedad es referida como Quemadura Foliar Bacterial (BLS, por sus siglas en inglés). Los Arboristas, los propietarios y las comunidades están ahora empezando a reconocer BLS como una amenaza seria para los bosques urbanos. Mientras los avances en las técnicas de diagnóstico han habilitado a los Arboristas para diagnosticar BLS, hay muchas interrogantes que aún permanecen sin respuesta con relación a rango del hospedero, transmisión, patogénesis, manejo de la enfermedad y terapia de los árboles individuales. 